\title{
EVALUATION OF THE COST DRIVERS AND ALLOCATION FRAMEWORK IN OUTBOUND LOGISTICS OF THE FAST-MOVING CONSUMER GOODS INDUSTRY
}

\author{
H.J. van Niekerk ${ }^{1 \#}$ \& W.L. Bean ${ }^{1 *}$
}

\section{ARTICLE INFO}

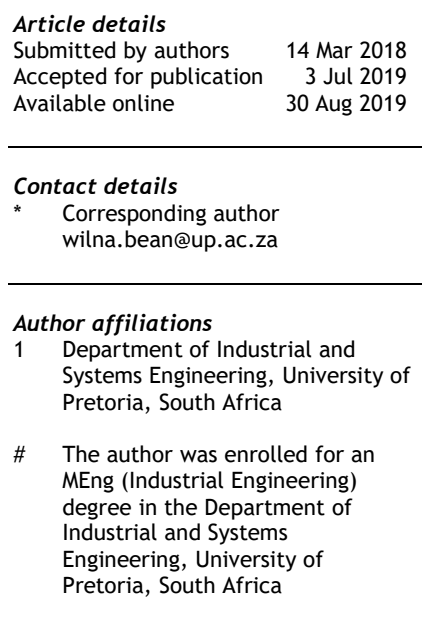

DOI

http://dx.doi.org/10.7166/30-2-1943
The fast-moving consumer goods industry is a complex trading environment, with many companies experimenting with various ways to increase profit. Outbound logistics, as an integrated concept within supply chain management, remains a key focus area for companies due to the high costs involved. The reality, however, is that often companies do not understand the outbound logistics cost drivers, and hence the profitability of current (let alone new) channels, regions, products, and customers. This is simply due to insufficient information being available from traditional accounting statements. The study evaluates the outbound logistics cost drivers of the South African fast-moving consumer goods industry, and describes an outbound logistics cost allocation framework.

\section{OPSOMMING}

Die vinnig bewegende verbruikergoedere (VBV) industrie is ' $n$ komplekse handelsomgewing waar menigte maatskappye eksperimenteer met verskeie metodes om winsgewendheid te verbeter. Uitgaande logistiek, as 'n geïntegreerde konsep as deel van vervoerkanaal-bestuur, bly ' $n$ belangrike fokusarea vir maatskappye weens die hoë koste daaraan verbonde. Die realiteit is egter dat maatskappye dikwels nie die dryfveer van logistieke koste verstaan nie, en dus ook nie die winsgewendheid van huidige (of nuwe) kanale, streke, produkte en kliënte nie. Dit is bloot as gevolg van onvoldoende inligting beskikbaar vanaf tradisionele rekeningkundige state. Die studie evalueer dus die uitgaande logistieke kostebestuurders van die Suid-Afrikaanse VBV-industrie en beskryf ' $n$ uitgaande logistieke koste toekenningsraamwerk.

\section{INTRODUCTION}

"South Africa's logistics costs totalled R429 billion in 2014 and equated to $11.2 \%$ of gross domestic product (GDP) or $51.5 \%$ of transportable GDP. Logistics costs increased by $9.2 \%$ between 2013 and 2014" 129[1]. Relatively low operating profit margins in the fast-moving consumer goods (FMCG) industry necessitate the reduction of logistics costs while maintaining acceptable service standards to its customers [2].

Barloworld Logistics [3], in their supplychainforesight report, state that, in line with previous surveys, it is clear that logistics operating costs are still a big constraint of a business. It is therefore "more prudent to understand the relationship of costs relative to the value they derive" [3]. The true determination of the sources of profit and/or profit erosion is clearly a growing need. It is important to understand the real cost of services and the cost efficiency of activities contributing to logistics services, by enhancing the capabilities of management accounting systems [4]. This understanding provides valuable insights into sustainability aspects and highlights possible corrective actions.

The enhancement of management accounting systems was recognised by Christopher [5], who stated that traditional cost accounting procedures often provided unreliable insight into profitability. 
Activity-based costing $(A B C)$ is not a new concept, and was introduced to solve the distortion problems of traditional costing systems [6]. This costing methodology started out by focusing predominantly on manufacturing because of the significant costs involved; but it can be a useful tool in logistics management [7]. Using $A B C$ to assign costs to determine the profitability of customers and products is widely accepted [8].

The research problem reads as follows: Evaluating and defining outbound logistics cost drivers for FMCG companies is essential to create a cost-to-serve (CTS) framework that will provide an understanding of the true impact of outbound logistics costs on differentiated customers, products, channels, and/or geographical regions.

The following three inductive conjectures were tested:

1. Current accounting systems provide insufficient insight into the outbound logistics CTS on a product and customer level. The development of an alternative CTS allocation framework, underpinned by cost drivers, is required to translate and assign costs logically to customer transactions to determine the true CTS.

2. The cost drivers of outbound logistics in the South African FMCG industry are not well defined or understood. This is a key component to developing cost allocation logic for each cost driver on a customer transactional level.

3. An outbound logistics CTS allocation framework is a critical component of supply chain optimisation, as (i) cost is linked to actual activity, (ii) it leads to a business understanding of costs and cost drivers, and (iii) it acts as a tool to identify customer servicing strategies to improve service and profit.

The primary research objective of this study was to evaluate the cost drivers for outbound logistics to develop a cost allocation framework within a South African FMCG industry context. The research considered non-empirical as well as empirical study strategies.

1. 'Non-empirical' entailed a literature review (as a source of historical evidence) to identify the characteristics of outbound logistics in the South African FMCG industry, and to understand current cost allocation methodologies and their application to the field of outbound logistics within the FMCG industry.

2. 'Empirical' entailed market interviews with three major FMCG companies (based on a questionnaire), and the validation of the CTS framework through a case study application.

3. The research is concluded by a synthesis of the hypotheses and the actual findings, with conclusions and recommendations.

\subsection{The FMCG industry}

FMCG, also known as 'consumer-packaged goods', are characterised by a quick rate of sale, and do not require an extensive decision-making process or financial investment for purchase [9]. Examples of products include a wide range of frequently purchased products, such as food, beverages, tobacco, household products, confectionery, toiletries, and health and beauty products.

FMCG has many characteristics that distinguish it from other industries, including the following [2][9]:

- $\quad$ Demand is seasonal, and fluctuates with changes in consumer disposable income, tastes, and preferences. Sales cycles typically peak on weekends, at month ends, and over the Easter and Christmas periods.

- $\quad$ Profit margins on FMCG products, especially at retail level, are usually low, but large quantities are sold.

- Due to relatively low levels of customer loyalty, product branding and availability are extremely important. 'Disloyalty' occurs frequently when the product of choice is not available and an alternative brand is substituted. The industry therefore realised that it is difficult to win in the market on price alone - supply chain speed, responsiveness, and flexibility are critical to maintaining a competitive edge.

The FMCG industry is a complex, dynamic, and low-margin trading environment, and many companies are experimenting with various ways to increase profit. Supply chain optimisation, including outbound logistics, remains a key focus area due to the high costs involved. 


\subsection{The supply chain and outbound logistics}

The Association for Operations Management (APICS) states that a supply chain is "a global network used to deliver products and services from raw materials to end customers through an engineered flow of information, physical distribution, and cash" [10]. Outbound logistics, a subset of supply chain management, is further defined as "every process that is involved in the shipping and holding of products after they are completed until they are received by the customer" [10]. Outbound logistics, within a simplified supply chain, is shown in Figure 1.

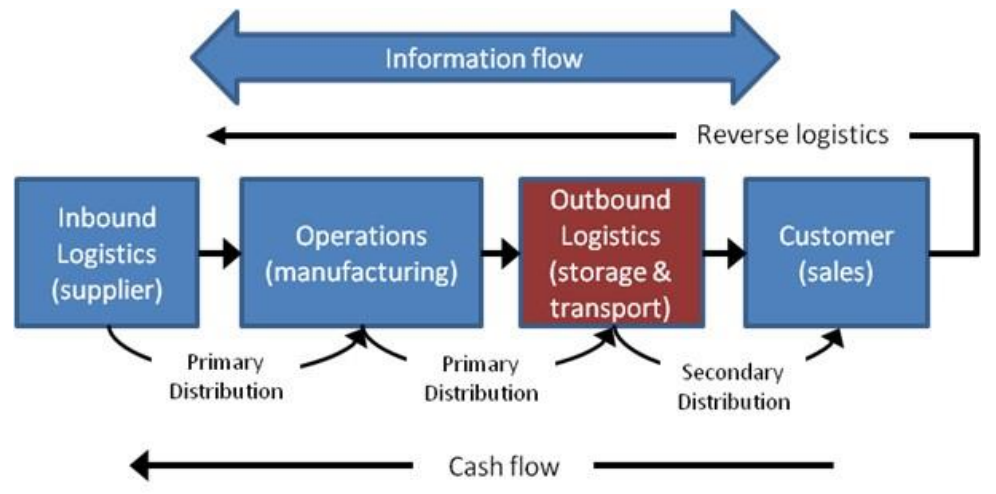

Figure 1: Simplified view of a supply chain, including outbound logistics

The logistics function can be the key facilitator in the cross-functional effort for supply chain integration to meet future needs, which are now assumed to be of strategic importance. Retaining and sustaining financial returns is the supreme objective, and "the real opportunity lies in a company's ability to ensure costs are managed in relation to creating value going forward" [3]. This supports the viewpoint and familiar phrase that "customer service involves getting the right product, to the right customer at the right place, in the right condition, at the right time at the lowest possible cost" [11].

Since 2013, with estimations for 2015 and 2016, South Africa's overall logistics costs as a percentage of GDP are on the increase [1]. Logistics costs comprise mainly four components: transport costs, inventory carrying costs, warehousing, and management and administration [12]. Transport costs contribute more than 55 per cent of logistics costs, and are increasing [1].

South Africa's vast geographic size presents a further challenge for companies to minimise logistics costs while maintaining, or even improving, reliable customer service. Expressing logistics costs as either a percentage of revenue or in Rands per unit over-simplifies both measures. Merely breaking down logistics into high-level cost categories will provide insight and identify focus areas. However, understanding the true CTS (and resulting profitability) on a more granular customer and product level will produce a fitting logistics improvement agenda for different supply chains within a company.

The study therefore focuses on developing a customised CTS framework for the South African FMCG industry that evaluates the cost components and cost drivers for each outbound logistics process namely, (i) primary distribution, (ii) warehousing/storage, and (iii) secondary distribution.

\section{COST DRIVERS IN OUTBOUND LOGISTICS}

To determine the true CTS of outbound logistics in businesses, the cost drivers associated with the logistics processes and activities need to be evaluated. This section therefore provides an overview of current financial reporting for logistics management; and how costing allocation methodologies can be applied to improve the accuracy and understanding of logistics costs to overcome the shortfalls of traditional accounting practices. The method of identifying cost drivers is also discussed, as it is an essential part of the process to measure a company's logistics costs performance on a more granular level. 


\subsection{Financial reporting}

Retaining and sustaining financial returns is the supreme objective, and "the real opportunity lies in a company's ability to ensure costs are managed in relation to creating value going forward" [3]. Profitability measurement is a key FMCG business objective - to improve return on equity (ROE) for the company shareholders [13]. In simple terms, ROE equals net profit divided by equity. It is therefore clear that this involves both the maximisation of income statement value (net profit) and the optimisation of the balance sheet (equity) items. In the context of the scope of this study, outbound logistics impacts both net profit (since it is a customer service cost) and equity (if it is an owned fleet and therefore an asset).

Income statements or management accounts are traditionally set up such that logistics costs are reported on an aggregated level in the income statement (also known as the profit and loss account) as an overhead, and not at an individual customer or product level [14]. Businesses still do not have the financial controls to understand the true cost of the product or service they sell, which is required to calculate customer or product profitability [15].

Considering standard accounting practices, the gross contribution after production is usually easy to obtain from the income statement at company level. To convert from this to customer and product profitability does, however, require the fair allocation of sales, marketing, and logistics costs to customer transactions. The value is not just the overall answer of customer profitability, but also the understanding of what drives the cost to ensure alignment between stakeholders.

\subsection{Management accounting: Activity-based costing and throughput accounting}

$A B C$ is a management accounting methodology that measures the cost of activities based on an allocation logic that recognises the causal relationships of cost drivers with activities [16]. A cost driver can be defined as something that causes costs because it consumes resources [5]. The ABC methodology has been around since the early 1980s, and was first advocated by Harvard Business School Professor Robert S. Kaplan. The concept of activity-based costing was designed to solve the distortion problems of traditional costing systems [6]. Stapleton [17] illustrated that ABC identifies cost pools and assigns them to products or services based on the number of events associated with the process of providing such products or services.

Management accounting methodologies improved cost accounting for many companies, since they could offer more accurate product costs than could traditional accounting systems. $A B C$ began focusing mainly on manufacturing because of the significant costs involved; but the methodology can be applied to other fields, including logistics [18]. Considering the increasing cost of logistics, and that such costs are usually buried in overheads, $A B C$ is being used more frequently in logistics to understand these costs [17].

The following are important to understand about $A B C[16]$ :

1. Activities are tasks that consume resources and result in the completion of the product or service. It is therefore important to distinguish between value-adding and non-value adding activities.

2. The cost objective is the final product or service created as a result of the activities mentioned in the previous point.

3. Resources are the 'ingredients' necessary to 'produce' the goods or service.

4. A cost driver is a variable, with a rational cause-and-effect relationship between the use of the resource, the performance of activities, and the cost objectives.

5. Operational cost drivers, or causes of cost, are those variables that determine the workload and so explain why activities are performed.

Another philosophy challenging existing cost accounting and productivity improvements is the theory of constraints (TOC), developed by Dr Eli Goldratt in the early 1980s [19]. TOC proposes an alternative accounting structure, called throughput accounting (TA), which consists of the three basic operating measures of throughput, inventory, and operating expense [20][21][22]. One of the fundamental differences between $A B C$ and $T A$ is how each deals with fixed and variable costs. These costs are defined as follows [23]: 
- Variable cost is defined as the cost that changes when the total product changes; therefore it corresponds to the cost of variable inputs. It is also referred to as direct costs, prime costs, or avoidable costs. In logistics, these costs can be defined as the costs associated with the activity of distribution, and include costs such as fuel, tyres, and toll fees.

- $\quad$ Fixed cost is defined as a cost that remains constant irrespective of the quantity of output produced. These are therefore the costs incurred when no activity occurs, and include overheads and indirect or unavoidable costs. In terms of distribution, fixed costs will be incurred whether the vehicle moves or is stationary. For vehicles this will include depreciation, vehicle licences, insurance, and permanent driver and assistant salaries.

$A B C$ splits costs between variable (direct) and fixed (indirect), which is not the same as for TA, which does not see the split as useful. This is mainly because manufacturing, where TA is mostly applied, is typically considered an indirect or fixed cost [21][22][24][24]. However, this is not the case for outbound logistics, which has variable costs.

In conclusion, the $\mathrm{ABC}$ methodology measures the cost and performance of products by assigning a resourcing cost to activities, and therefore recognises that there is a causal relationship of cost drivers with activities [16]. The underlying principle of the $A B C$ methodology is therefore the identification of cost drivers for the activity to which it will be applied. The purpose of this study evaluating the cost drivers for outbound logistics in the FMCG industry to determine the true CTS has a strong correlation with the $A B C$ methodology [25].

\subsection{Identifying cost drivers}

A company needs to clearly define the costs associated with deploying resources/activities within the outbound logistics processes, and then ascertain the cost driver behind each activity. The following steps are recommended to identify the cost drivers for a function or process [17]:

1. Create a process overview of the activities performed. This is important, as it identifies all the activities performed in the scope of the function being studied.

2. Obtain data on activities performed. This includes the quantity and type of activities required to produce/supply in each step of the process.

3. Determine the costs associated with the process; therefore, source all the relevant costs (fixed and variable) associated with the process.

4. Allocate costs to each activity or group of activities. It is important that the understanding of costs and activities be sufficient to allow for the correct allocation of costs. In many instances, fixed costs will need to be allocated to more than one group of activities.

5. Critically evaluate each group of activities. This helps determine which activities are cost effective, and steps can then be initiated to reduce costs or increase profit. The implementation of these changes is known as activity-based management.

The accuracy of $A B C$ relies on understanding the cost of outbound logistics, the activities performed, and the associated cost drivers. Table 1 summarises the likely cost drivers for the outbound logistics environment, split between warehousing and distribution [17][26][27].

\section{MARKET INTERVIEWS}

A questionnaire was used during the market interviews with three major FMCG companies to obtain information on current events to enrich the non-empirical findings. The questionnaire was structured around the following key questions:

1. Do current accounting systems and reporting techniques provide sufficient insight into true logistics costs at a product and customer level?

2. What are the cost drivers of outbound logistics activities in the FMCG industry?

3. What are the potential benefits of designing an outbound logistics cost-to-serve (CTS) framework? 
Table 1: Literature study of outbound logistics cost drivers

\begin{tabular}{|c|c|c|c|}
\hline Process & $\begin{array}{l}\text { Activity } \\
\text { group }\end{array}$ & Activities & Cost drivers \\
\hline \multirow{9}{*}{ 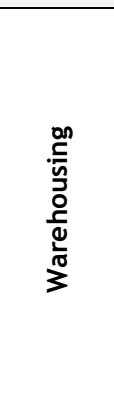 } & \multirow[t]{4}{*}{ Handling in } & $\begin{array}{l}\text { Unloading incoming } \\
\text { goods }\end{array}$ & Quantity and packaging (pallets/cases/units) \\
\hline & & Palletise & Quantity and packaging (pallets/cases/units) \\
\hline & & Check incoming goods & $\begin{array}{l}\text { Quantity and packaging (pallets/cases/units) as well } \\
\text { as the quality of the supplier }\end{array}$ \\
\hline & & Put away & Quantity and packaging (pallets/cases/units) \\
\hline & \multirow[t]{2}{*}{ Storage } & Storage & Shelf space used \\
\hline & & Replenishment & Quantity \\
\hline & \multirow[t]{3}{*}{$\begin{array}{l}\text { Handling } \\
\text { out }\end{array}$} & Picking ${ }^{1}$ & $\begin{array}{l}\text { Quantity and packaging (pallets/cases/units) as well } \\
\text { as number of visits to the pick location }\end{array}$ \\
\hline & & Packaging and labelling & Number of orders picked \\
\hline & & Load outgoing goods & Quantity \\
\hline \multirow{4}{*}{ 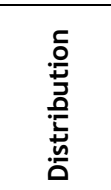 } & \multirow[t]{4}{*}{ Transport } & Delivery to site & Distance and $\mathrm{m}^{2}$ of pallet throughput \\
\hline & & Trucking & Distance and $\mathrm{m}^{2}$ of pallet throughput \\
\hline & & Unloading at customer & Number of consignments and type of consignee \\
\hline & & Sorting & $\begin{array}{l}\text { Number of consignments and number of } \\
\text { cases/pallets per consignment }\end{array}$ \\
\hline
\end{tabular}

\subsection{Interview results}

The following key outcomes are evident from the interviews:

1. Current accounting procedures provide insufficient detail about the true CTS at customer or product level. At best, all customers and products are treated equally when allocating logistics costs at a high-level.

2. Understanding the outbound logistics cost drivers and true CTS at a customer and product level will provide significant insights - for example:

a. Customer and product margin contribution (profitability) can be calculated to decide which customers and products to retain;

b. Understanding the logistics cost drivers associated with service levels.

3. The operating cost of the outbound logistics processes is easy to ring-fence, and it is important to differentiate between fixed and variable costs.

4. Outsourcing of logistics services is still prevalent; and it is worth noting that the cost drivers are likely to differ between in-house and outsourced logistics activities, mainly due to the charge model agreed with the logistics service provider.

5. It is possible to define a generic list of cost drivers for each outbound logistics activity that could be representative of the FMCG industry.

All interviewees agreed that the outbound logistics CTS at both customer and product level is an important consideration, and that current financial systems do not adequately meet this requirement. The evaluation of the cost drivers and development of an outbound logistics CTS framework will provide valuable profitability insights and internal company alignment to drive the correct behaviour and decisions.

\section{COST DRIVER FRAMEWORK DEVELOPMENT}

One of the main focuses of this study, which includes the definitions of fixed and variable cost and cost drivers for each outbound logistics process and associated activities, is to identify cost drivers that can be applied in the FMCG industry. This is important in the process of moving from conventional financial reporting methods to a method of calculating the true CTS, which requires fair and detailed allocation of all logistics operating costs.

\subsection{Evaluation of cost drivers}

The recommended activities, cost components, and cost drivers are an amalgamation of the literature study and market interview responses.

Picking is the "process of withdrawing goods from stock to ship to a distribution warehouse or to a customer" [1]. 


\subsubsection{Primary distribution}

Table 2 provides a description of the cost drivers, activity inputs, cost components, and CTS outputs for the primary distribution process.

Table 2: Primary distribution cost drivers

\section{Primary distribution}

This is the activity of transporting products from manufacturing sites to storage locations, or between storage locations. The product is typically moved in full pallet quantities, and the distribution capacity is constrained by the number of pallets per load. The volume of pallets to be transported determines the number of primary distribution loads and resultant operating costs.

\begin{tabular}{|c|c|c|c|}
\hline Cost driver & Activity inputs & Cost components & Output \\
\hline Pallets & $\begin{aligned} & \text { i. } \text { Actual pallets } \\
& \text { transported } \\
& \text { ii. }\end{aligned}$ & $\begin{array}{l}\text { Own fleet: } \\
\text { i. } \quad \text { Fixed cost, inter alia: } \\
\text { - Vehicle drivers and assistants } \\
\text { - Depreciation or lease amount } \\
\text { - Insurance } \\
\text { ii. Variable cost, inter alia: } \\
\quad \text { - Fuel, tyres, lubrication } \\
\text { - Maintenance } \\
\text { Outsourced transport: } \\
\text { Transport rate (e.g., Rand/lane, } \\
\text { Rand/pallet, etc.) }\end{array}$ & Rand/pallet \\
\hline
\end{tabular}

\subsubsection{Warehousing}

The warehouse cost allocation is based on the principle that different activities within the warehouse attract different costs and have dissimilar cost drivers. Warehousing is therefore split into three main activities: (i) handling-in, (ii) storage, and (iii) handling-out. Table 3 provides a description of the cost drivers, activity inputs, cost components, and CTS outputs for each respective warehousing activity.

Table 3: Warehousing cost drivers

\section{Warehouse activity: Handling-in}

The activity of receiving the product at the warehouse and moving it to storage. The product is usually delivered in full pallet quantities. The handling workload is therefore a function of the number of pallets received.

\begin{tabular}{|c|c|c|c|}
\hline Cost driver & Activity input & Cost components & Output \\
\hline Pallets & $\begin{array}{cl}\text { i. } & \text { Number of pallets received } \\
\text { ii. } & \text { Handling-in operating cost }\end{array}$ & $\begin{array}{l}\text { Partial cost inclusion of: } \\
\text { i. Material handling equipment } \\
\text { ii. People/labour }\end{array}$ & Rand/pallet \\
\hline \multicolumn{4}{|c|}{ Warehouse activity: Storage } \\
\hline \multicolumn{4}{|c|}{$\begin{array}{l}\text { The activity of storing the product. Generally, the cost associated with storage is fixed, and is constrained } \\
\text { by the number of pallet positions (or bin locations) available for storing the product. }\end{array}$} \\
\hline Cost driver & Activity input & Cost components & Output \\
\hline Pallets stored & $\begin{aligned} \text { i. } & \text { Storage capacity (pallets) } \\
\text { ii. } & \text { Stacking height per stock } \\
& \text { keeping unit (SKU) } \\
\text { iii. } & \text { Stock on hand (pallets) }\end{aligned}$ & $\begin{array}{l}\text { All fixed costs relating to the } \\
\text { storage facility (building, municipal } \\
\text { services, etc.) }\end{array}$ & $\begin{array}{l}\text { Rand/pallet/ } \\
\text { SKU }\end{array}$ \\
\hline \multicolumn{4}{|c|}{ Warehouse activity: Handling-out } \\
\hline \multicolumn{4}{|c|}{$\begin{array}{l}\text { The activity of picking, moving the product to the dispatch bay, and loading the vehicles. The product } \\
\text { picked and loaded could be in either full pallets or part-pallets (known as break bulk). }\end{array}$} \\
\hline Cost driver & Activity input & Cost components & Output \\
\hline $\begin{array}{l}\text { Full pallet and } \\
\text { break-bulk } \\
\text { picking }\end{array}$ & $\begin{array}{l}\text { Picking and loading volumes - } \\
\text { split between full and part- } \\
\text { pallet picking }\end{array}$ & $\begin{array}{l}\text { Partial cost inclusion of: } \\
\text { i. Material handling equipment } \\
\text { ii. People/labour }\end{array}$ & $\begin{array}{l}\text { Rand/pallet/ } \\
\text { SKU }\end{array}$ \\
\hline
\end{tabular}

\subsubsection{Secondary distribution}

Table 4 provides a description of the cost drivers, activity inputs, cost components, and CTS outputs for the secondary distribution process. 
Secondary distribution

The activity where a loaded vehicle delivers to the end customer. Generally, a vehicle performs multiple deliveries on a route. This activity has two key constraints: (i) distance travelled to the customer, and (ii) the turnaround time at the customer to make the delivery.

\begin{tabular}{|c|c|c|c|}
\hline Cost driver & Activity input & Cost components & Output \\
\hline $\begin{array}{l}\text { i. } \begin{array}{l}\text { Customer's distance } \\
\text { (kilometres) from the }\end{array} \\
\text { facility } \\
\text { ii. Delivery turnaround time } \\
\text { at the customer } \\
\text { iii. Number of deliveries }\end{array}$ & $\begin{aligned} & \text { i. } \begin{array}{l}\text { Number of } \\
\text { deliveries to a } \\
\text { customer }\end{array} \\
& \text { ii. } \text { Volume (e.g., } \\
& \text { pallets) delivered } \\
& \text { iii. } \text { Secondary } \\
& \text { transport cost }\end{aligned}$ & $\begin{array}{l}\text { Own fleet: } \\
\text { i. } \quad \text { Fixed cost, inter alia: } \\
\text { - Vehicle drivers/assistants } \\
\text { - Lease and/or } \\
\text { depreciation } \\
\text { ii. Variable cost: } \\
\text { - Fuel, tyres, lubrication } \\
\text { - Maintenance } \\
\text { Outsourced fleet: } \\
\text { Delivery rate (e.g. R/ton, } \\
\text { R/delivery, etc.) }\end{array}$ & R/pallet \\
\hline
\end{tabular}

\subsection{CTS framework}

The CTS framework is not intended to replace the general ledger accounts, but should rather be used as a diagnostic tool to understand outbound logistics costs at a much lower level (as well as the associated cost drivers). This section describes a cost allocation framework for each outbound logistics process, based on the identified cost drivers for each activity discussed in the preceding section.

\subsubsection{Primary distribution}

Table 5 suggests a cost allocation framework for the primary distribution process.

Table 5: Primary distribution cost allocation framework

\begin{tabular}{|c|c|c|c|c|}
\hline \multicolumn{5}{|c|}{ Primary distribution } \\
\hline $\begin{array}{l}\text { Owner- } \\
\text { ship }\end{array}$ & $\begin{array}{l}\text { Cost } \\
\text { driver }\end{array}$ & Activity variables & Calculation & Output \\
\hline 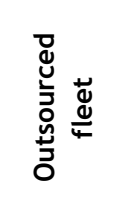 & 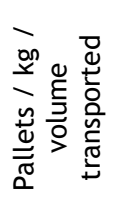 & $\begin{array}{l}\text { Example: } \\
\text { - } \mathrm{P}=\text { total pallets per lane per SKU } \\
\text { - } \mathrm{T}=\text { trips per lane } \\
\text { - } \mathrm{R}=\text { lane rate } \\
\text { - } \mathrm{CPP}=\text { cost per pallet }\end{array}$ & $C P P=\frac{(T \times R)}{P}$ & Rand/pallet \\
\hline 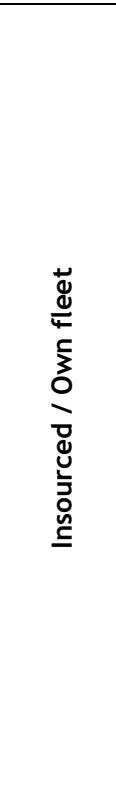 & 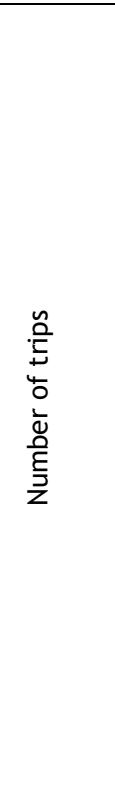 & $\begin{array}{l}\text { - } \mathrm{TAT}=\text { turnaround time at delivery } \\
\text { location } \\
\text { - } \mathrm{TA}=\text { total TAT for all trips } \\
\text { - } \mathrm{d}=\text { distance }(\mathrm{km}) \text { between } \\
\text { dispatch and receiving locations } \\
\text { (nodes) } \\
\text { - } \mathrm{dT}=\text { total distance for all trips } \\
\text { - } \mathrm{S}=\text { average travel speed between } \\
\text { nodes }(\mathrm{km} / \mathrm{h}) \\
\text { - } \mathrm{T}=\text { number of trips between nodes } \\
\text { - } \mathrm{P}=\text { total pallets delivered/lane } \\
\text { - } \mathrm{F}=\text { fixed cost } \\
\text { - } \mathrm{V}=\text { variable cost } \\
\text { - } \mathrm{X}=\text { time ratio/node } \\
\text { - } \mathrm{FL}=\text { fixed cost/lane } \\
\text { - } \mathrm{VL}=\text { variable cost/lane } \\
\text { - } \mathrm{FLP}=\text { fixed cost per pallet per } \\
\text { lane } \\
\text { - } \mathrm{VLP}=\text { variable cost per pallet per } \\
\text { lane } \\
\text { - } \mathrm{TLP}=\text { total cost/pallet/lane }\end{array}$ & $\begin{array}{l}\text { Fixed cost per lane: } \\
X\left(\frac{\left(T A T+\left(\frac{d}{s}\right)\right) * T}{(T A)}\right) \\
\text { Then; } \\
\text { Then; } F L=X \times F \\
\qquad F L P=\frac{F L}{P} \\
\text { Variable cost per lane: } \\
\quad V L=\left(\frac{d \times T}{d T}\right) \times V \\
\text { Then; } \quad V L P=\frac{V L}{P} \\
\text { Total cost per lane: } \\
T L P=F L P+V L P\end{array}$ & $\begin{array}{l}\text { Rand } \\
\text { Rand/pallet } \\
\text { Rand }\end{array}$ \\
\hline
\end{tabular}




\subsubsection{Warehousing}

Table 6 gives a breakdown of each of the activities costed, and provides the calculation that will be applied to allocate warehousing cost per SKU for each activity.

Table 6: Warehouse cost allocation framework

\begin{tabular}{|c|c|c|c|c|}
\hline Activity & Cost driver & Activity variables & Calculation & Output \\
\hline $\begin{array}{l}\text { Handling- } \\
\text { in }\end{array}$ & Pallets & $\begin{array}{l}\text { - } \mathrm{P}=\text { pallets received } \\
\text { - } \mathrm{HI}=\text { handling-in cost } \\
\text { - } \mathrm{HICP}=\text { handling-in } \\
\text { cost per pallet }\end{array}$ & $H I C=\frac{H I}{P}$ & $\begin{array}{l}\text { Rand/pallet } \\
\text { /SKU }\end{array}$ \\
\hline Storage & Pallets & $\begin{array}{l}\text { - } \mathrm{SOH}=\text { average pallets } \\
\text { stock on hand per SKU } \\
\text { in location } \\
\text { - } \mathrm{H}=\text { stacking height } \\
\text { per SKU } \\
\text { - } \mathrm{SC}=\text { storage cost } \\
\text { - } \mathrm{ASOH}=\text { adjusted stock } \\
\text { on hand ( } \mathrm{n}=\text { number } \\
\text { of SKUs) } \\
\text { - } \mathrm{TSOH}=\text { total adjusted } \\
\text { SOH for all SKUs } \\
\text { - } \mathrm{n}=\text { number of SKUs } \\
\text { - } \mathrm{SCP}=\text { storage cost per } \\
\text { pallet per SKU }\end{array}$ & $\begin{array}{l}\text { ASOH }=\frac{S O H}{H} \\
\text { Then; } \\
\quad T S O H \\
=\sum_{1}^{n} A S O H \\
\text { Then; } \\
S C P=\frac{\frac{A S O H}{S S O H} * S C}{S O H}\end{array}$ & $\begin{array}{l}\text { Pallets/SKU } \\
\text { Pallets } \\
\text { Rand/pallet/SKU }\end{array}$ \\
\hline $\begin{array}{l}\text { Handling- } \\
\text { out }\end{array}$ & $\begin{array}{l}\text { Pallets (or } \\
\text { equivalent unit) } \\
\text { picked for dispatch }\end{array}$ & $\begin{array}{l}\text { P = pallets picked and } \\
\text { loaded for dispatch } \\
\text { - } \mathrm{HO}=\text { handling-out } \\
\text { cost } \\
\text { HOC = handling-out } \\
\text { cost per pallet }\end{array}$ & $\begin{array}{l}\text { Cost allocation per } \\
\text { pallet per location } \\
\qquad H O C=\frac{H O}{P}\end{array}$ & Rand/pallet/SKU \\
\hline
\end{tabular}

\subsubsection{Secondary distribution}

The secondary distribution cost is allocated per SKU per customer on a fixed and variable basis to account for vehicle operating (including labour) costs. The cost drivers for:

- $\quad$ Fixed costs are allocated per customer by apportioning the cost based on turnaround time (TAT) and time travelled to the customer.

- Variable costs are allocated per customer based on the distance from the depot.

Table 7 gives a breakdown of the costs and provides the calculation that will be applied to allocate the secondary distribution cost per SKU per customer.

\subsubsection{Consolidated view}

Each outbound logistics process and related activity can be translated into Rands per pallet per customer. This is based on the premise that, as the finished product moves physically along the supply chain from origin to the final storage location (before being sold), it will attract costs, since it consumes resources as defined by the cost driver. The reality is that the final product attracts logistics costs before being sold to a customer, which implies that the total CTS can only be allocated at a customer level once the product has been delivered (or collected by the customer). Primary distribution, Warehouse handling-in, and Warehouse storage activities are typical examples of outbound logistics processes that attract costs prior to the product being sold. Warehouse handlingout and Secondary distribution activities are triggered once a customer order is received, to prepare and deliver the product. 
Table 7: Secondary distribution cost allocation framework

\begin{tabular}{|c|c|c|c|c|}
\hline $\begin{array}{l}\text { Owner- } \\
\text { ship }\end{array}$ & $\begin{array}{l}\text { Cost } \\
\text { driver }\end{array}$ & Activity variables & Calculation & Output \\
\hline 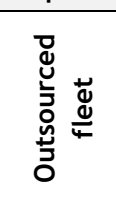 & 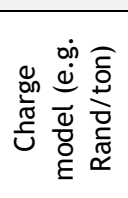 & $\begin{array}{l}\text { Example: } \\
\text { - } \mathrm{P}=\text { pallets delivered } \\
\text { - } \mathrm{D}=\text { tons delivered } \\
\text { - } \mathrm{R}=\text { rate charged }(\mathrm{e} . \mathrm{g} \mathrm{R} / \mathrm{ton}) \\
\text { - } \mathrm{TDC}=\text { total delivery cost }\end{array}$ & $T D C=\frac{(D \times R)}{P}$ & $\begin{array}{l}\text { Rand/pallet/ } \\
\text { customer }\end{array}$ \\
\hline 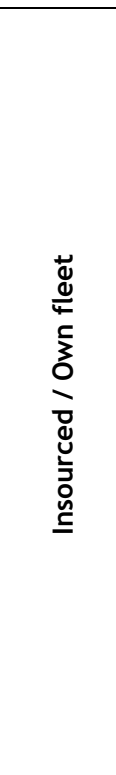 & 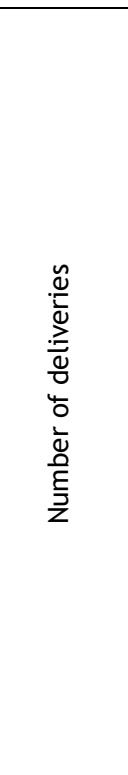 & $\begin{array}{l}\text { - } \text { TAT = customer average TAT } \\
\text { - TTAT = TAT time all } \\
\text { deliveries } \\
\text { - } \mathrm{d}=\text { distance from dispatch } \\
\text { point to customer }(\mathrm{km}) \\
\text { - } \mathrm{dT}=\text { distance of all deliveries } \\
\text { - } \mathrm{S}=\mathrm{km} / \mathrm{h} \text { to customer } \\
\text { - } \mathrm{P}=\text { pallets delivered to } \\
\text { customer } \\
\text { - } \mathrm{D}=\text { number of deliveries to } \\
\text { customer } \\
\text { - } \mathrm{F}=\text { fixed cost } \\
\text { - } \mathrm{V}=\text { variable cost } \\
\text { - } \mathrm{X}=\text { time ratio per customer } \\
\text { - } \mathrm{FC}=\text { fixed cost per customer } \\
\text { - } \mathrm{VC}=\text { variable cost/customer } \\
\text { - } \mathrm{FCP}=\text { fixed cost/pallet/lane } \\
\text { - } \mathrm{VCP}=\text { variable } \\
\text { cost/pallet/lane } \\
\text { - } \mathrm{TCP}=\text { total cost/pallet/lane }\end{array}$ & $\begin{array}{l}\frac{\text { Fixed cost per customer: }}{X}=\left(\frac{\left(T A T+\left(\frac{d}{s}\right)\right) \times D}{(T T A T)}\right) \\
\text { Then; } \\
\text { Then; } F C=X \times F \\
\qquad F C P=\frac{F C}{P} \\
\text { Variable cost per customer: } \\
V C=\left(\frac{d \times D}{d T}\right) \times V \\
\text { Then; } \quad V C \\
V C P=\frac{V C}{P}=R / p a l l e t \\
\text { Then; } \quad \text { TCP }=F C P+V C P\end{array}$ & $\begin{array}{l}\% \\
\text { Rand/ customer } \\
\text { Rand/pallet/ } \\
\text { customer } \\
\text { Rand } \\
\text { R/pallet/ } \\
\text { customer } \\
\text { R/pallet/ } \\
\text { customer }\end{array}$ \\
\hline
\end{tabular}

The CTS unit of measure for each outbound logistics process at a customer and product level can be expressed as Rands per pallet (R/pallet). The R/pallet at a customer and product level will likely be different due to the unique cost drivers for each activity as the product is stored and moved through the network to the customer. The CTS R/pallet at SKU level can also be expressed as R/case for the same SKU. For example, if the total logistics R/pallet for an SKU is R1,000, and one pallet contains 20 cases, then the R/case will be R50. Since the number of cases per pallet typically differs between SKUs, the R/case will be distinct for each SKU. The R/case can then be compared with the sales value per case, at SKU level, to - for example - calculate the CTS as a percentage of sales value. Continuing with the example: if the sales value is R100/case and the logistics CTS is R50/case, then it implies that the CTS as a percentage of sales value is 50 per cent. Incorporating other product costs (e.g., production) will allow a company to calculate the margin contribution at SKU and customer level.

The validation and expected benefits of the CTS framework were achieved through a case study application, illustrated in the next section.

\section{CTS FRAMEWORK VALIDATION (A CASE STUDY)}

A case study application is best for understanding difficult problems, and useful when analysing a problem in its natural setting [28]. This case study was conducted at a large South African-based FMCG company. The company's outbound logistics network includes numerous manufacturing and warehousing facilities with logistics capabilities to store and transport products. The product range exceeds 450 SKUs, delivered to more than 3,500 customers. Due to the sensitivity of the information presented, the name of the company will remain confidential.

\subsection{Cost driver allocation example}

A hypothetical example of an outbound logistics network is depicted in Figure 2. The data inputs and assumptions, for a predefined timeframe, are included in Table 8. 


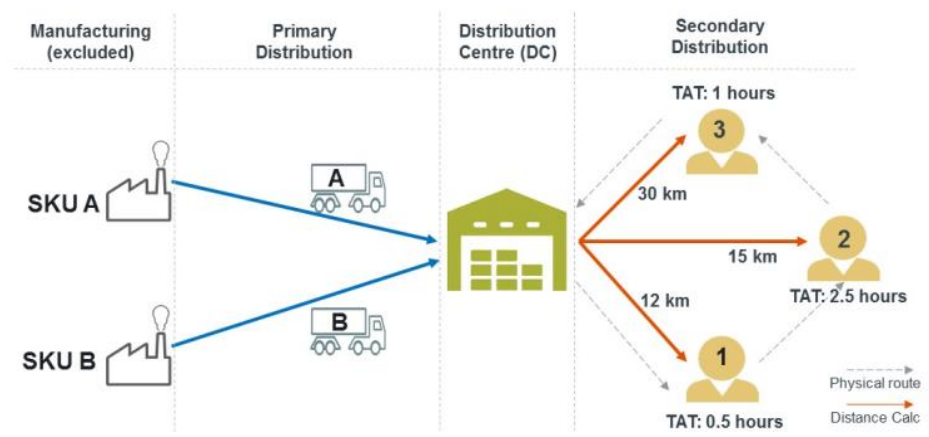

Figure 2: Case study supply chain example

Table 8: Case study data $\&$ assumptions

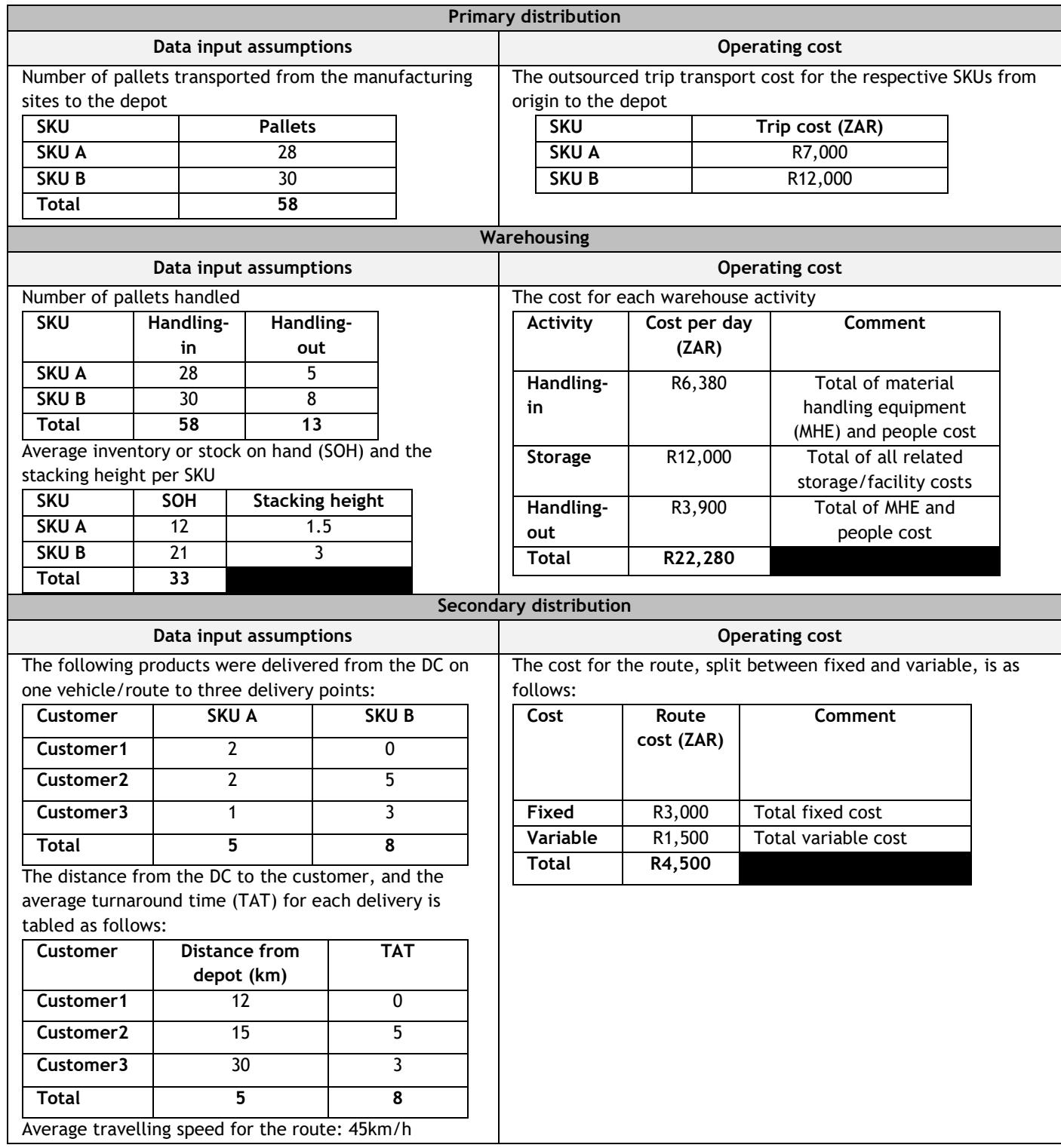

Considering the input assumptions for each process tabled above, the cost allocation can be calculated, guided by the CTS framework discussed in Section 4.2. The allocation results per product and per customer are illustrated in Table 9. 
Table 9: Case study allocation output

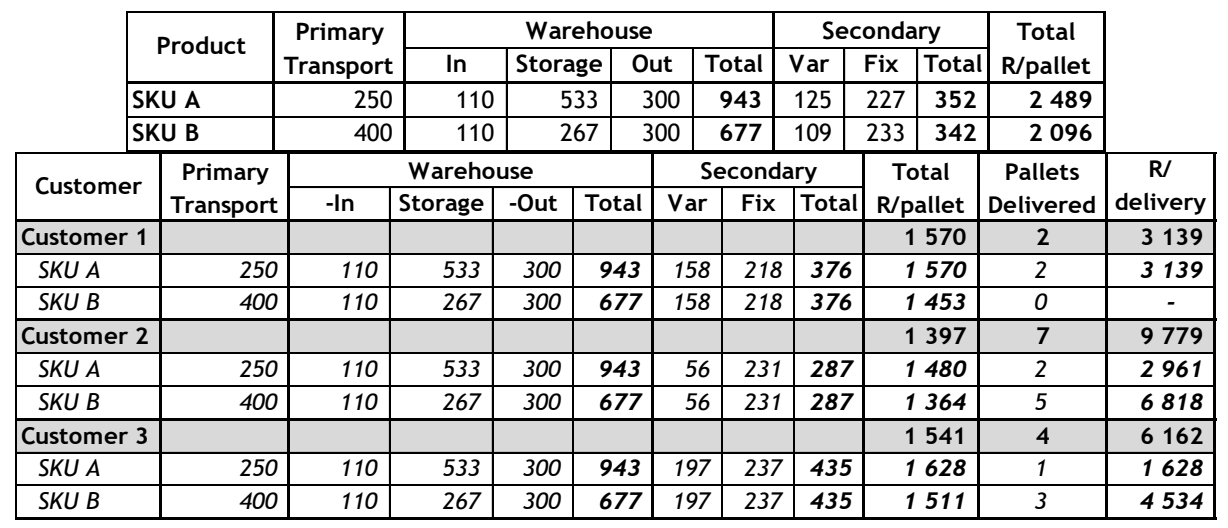

The calculations above yield the following insights:

1. Primary distribution: The R/pallet value varies at SKU level for the following reasons:

a. The path and distance an SKU physically moves through the supply chain, from origin to final storage destination, could differ. Therefore the allocated primary transport cost might be different - e.g., if an SKU pallet travels further, it will likely cost more.

b. The vehicle capacity and its use have an impact on the R/pallet (e.g., 28 versus 30 for each respective trip in the example above). The higher the vehicle utilisation, the lower the R/pallet. The vehicle capacity (in pallets) will also be a function of the SKU characteristics, and is usually constrained by either weight or volume.

2. Warehousing:

a. The R/pallet will be the same for all SKUs for the handling-in and handling-out activities. The only differentiation will be if the R/pallet is converted to R/case (if the number of cases stored on a pallet differs between SKUs).

b. The R/pallet for the storage activity is likely to be different between SKUs, since it is a function of the stock-on-hand levels and stacking configuration.

3. Secondary distribution: The R/pallet at product level will be the same for all SKUs for the same customer. However the R/pallet for the same SKU will likely differ between customers, since the distance travelled and the TAT to deliver the product are distinctive at a customer level. This also implies that the total R/delivery per customer will differ between customers (assuming varied distances and TAT).

The benefit of Table 9 is that, for each customer and each product, the delivery costs are known, compared with the sales revenue generated. It is therefore possible to calculate the profitability of a customer or product by comparing the delivery cost with the margin (before outbound logistics costs) of the goods sold.

To facilitate the interpretation and extraction of the most important results from this framework, a dashboard can be created. Thus the next section provides some examples of dashboards that can be used with the presented framework for decision-making.

\subsection{Cost-to-serve (CTS) dashboards}

The aim of this section is to provide an overview of potential CTS dashboards that can be created after applying the CTS framework. Note that the actual values of the company information used in the case study were substituted in the case study results to ensure confidentiality. For illustrative purposes, the delivered quantity will be measured in tons, pallets, and sales value.

Figure 3 summarises the CTS dashboard over a predefined time period. It contains the following information (labelled on the graph):

1. Key facts over the time period - e.g., total CTS, pallets delivered, CTS R/pallet, etc.

2. A total cost breakdown for each outbound logistics activity.

3. The total CTS, in Rands value, and expressed as a percentage of net invoiced value (NIV) for each depot. 
4. Reconciliation or verification that the total CTS balances with the actual management accounts or income statement.

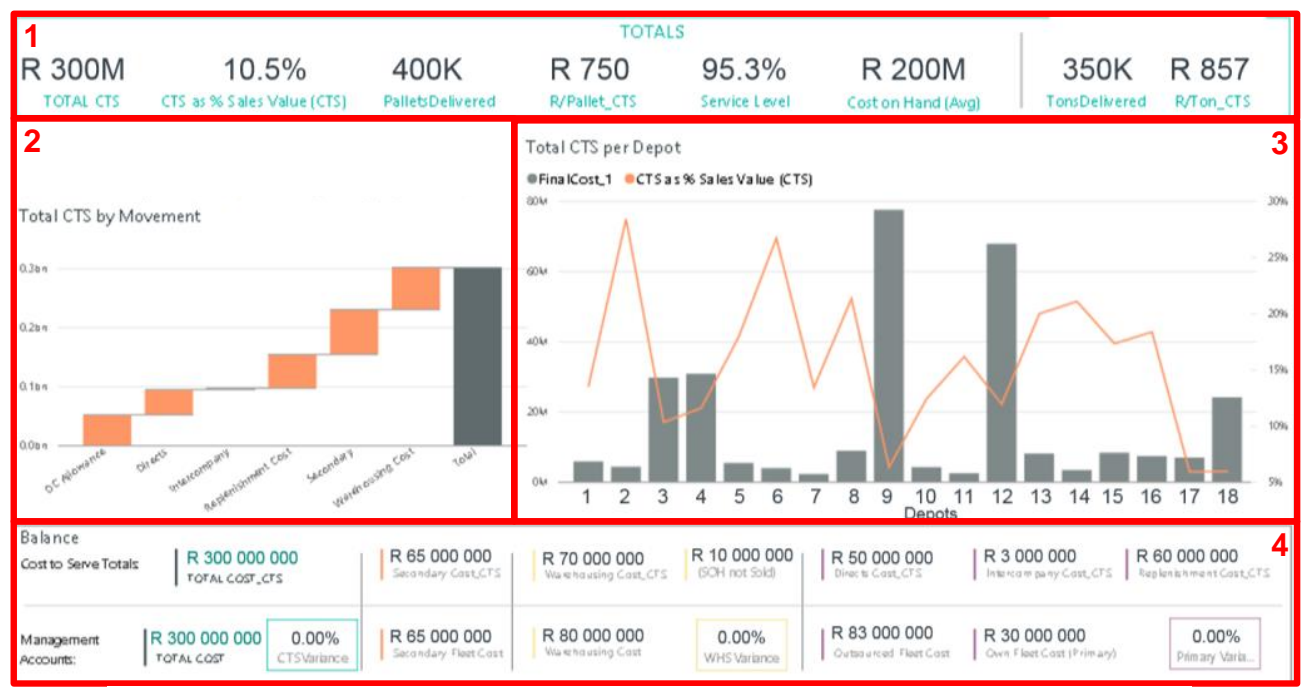

Figure 3: Case study dashboard (CTS summary)

The next dashboard (Figure 4) provides insight into the CTS for each individual customer (each dot represents a unique customer). This dashboard clearly illustrates the CTS as a percentage of a customer's NIV on the $y$-axis, and pallets delivered on the x-axis. In the table section of the figure, customers are grouped into CTS categories. A company could therefore quickly identify customers with a high CTS (e.g., $>20 \%$ of sales value) for further investigation. A similar dashboard could be developed at a product SKU level.

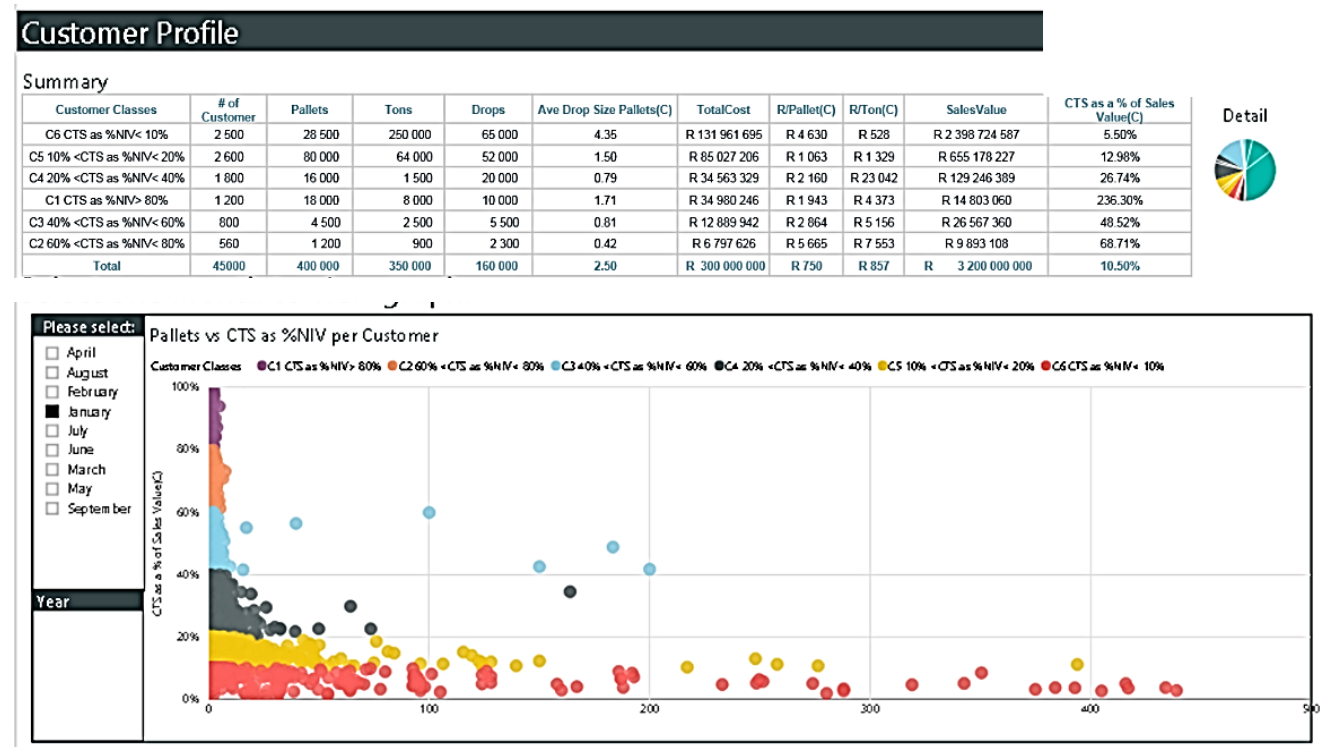

Figure 4: Case study customer classification (see online version for colour)

The company considers that an outbound logistics CTS (as a percentage of NIV) of greater than 40 per cent would completely erode its profit margins. From the results above, 27 per cent of the customers have a CTS greater than 40 per cent, which shows that these customers offset the profits of others.

The final dashboard (Figure 5) provides a comparison view of different business units (BUs) within the company, each having a unique supply chain. It is therefore possible to understand clearly each business unit's respective CTS (at a total and R/pallet or R/ton level), which would enable the 
determination of respective profitability. Even though the cost drivers for the business units are the same, the resultant margin contribution is substantially different.

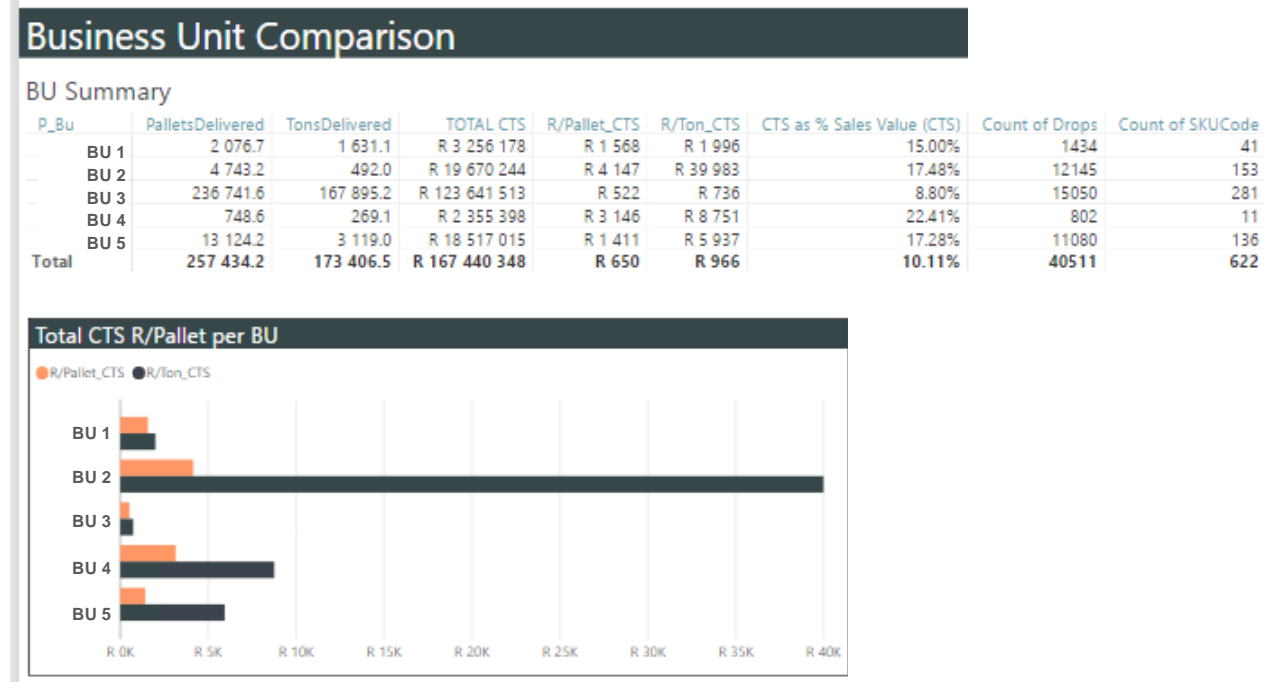

Figure 5: Case study business unit comparison

The following insights can be derived from the dashboard above:

a. BU3 has the highest SKU range and the highest sales (pallets) compared with the other BUs. At an aggregated level (not at customer or product level) it seems to be a profitable BU with a CTS of eight per cent of NIV.

b. BU4, on the other hand, has the smallest SKU range and low sales (pallets), with a relatively high CTS percentage $(>22 \%)$. It would be necessary to understand the percentage margin of each product (that could be higher for a high-value low-volume product, for example) before inferences can be made about profitability.

c. Expressing the CTS as R/pallet and R/ton differs between the BUs. The total R/pallet for BU2 is the highest. It is noteworthy that the R/ton for BU2 far exceeds that of the other BUs. This is due to the light weight of the product on the pallet. Since pallets are the handling unit in logistics operations, this illustrates the importance of appropriate metrics. For example, should the company measure CTS expressed as R/ton, it would completely distort the outcome and interpretation, and any benchmark would seem unreasonable. It is therefore recommended to express the CTS as R/pallet for comparison purposes between BUs.

\section{CONCLUSION}

The FMCG industry poses several unique logistics challenges, further complicated by the fact that financial statements are typically reported in business-function silos (e.g., marketing, production, administration, logistics, etc.) and not at a customer-transactional level. This is a major shortcoming, since FMCG companies need to understand the true cost-to-serve and resultant profitability of individual customer and product combinations. For this study, outbound logistics processes and activities were considered, as they are a significant cost contributor in the FMCG industry to deliver product to customers.

Based on the literature review, the controlled market interviews, and the validation of the suggested CTS allocation framework, the conclusions are:

- $\quad$ Hypothesis 1: Current accounting systems lack the insights to understand the outbound logistics CTS at a product and customer level. Being able to evaluate the CTS at a more detailed level is a key requirement to ensure that informed and appropriate business decisions are taken. The market interviews within the FMCG industry supported the notion that a CTS allocation framework, based on defined cost drivers, could be a critical input to supply chain optimisation and overall business profitability. 
- $\quad$ Hypothesis 2: The market interviews indicated that the cost drivers for outbound logistics in the FMCG industry are not well defined. However, the literature study and structured interview questions revealed that standard cost driver(s) for each outbound logistics process and related activities can indeed be defined, even though slight variations might exist due to different supply chain intricacies. However, the principle of using the cost driver(s) to develop a CTS allocation framework at a customer and product level holds true.

- $\quad$ Hypothesis 3: The study established that it is probable that costs can be ring-fenced for the respective outbound logistics processes. Evaluating the cost drivers for the activities associated with the processes will lead to a better understanding of the logistics costs and their drivers. The suggested CTS allocation framework determines the true CTS at a customer and product level, and is therefore a valuable decision-support tool to identify improvement initiatives and optimisation. Applying the tool to shape customer servicing strategies while reducing the outbound logistics CTS (and hence increase profit) is a significant competitive advantage.

The outcomes of the study can assist FMCG companies to understand the cost components and associated cost drivers for the activities related to outbound logistics. The contribution to the scientific knowledge base is in the form of a cost allocation framework that can enable FMCG companies to determine and evaluate the outbound logistics CTS at a customer and product level. Appropriate business and continuous improvement decisions can be taken, based on the results obtained from the framework. The framework can also serve as a foundation for future research that aims to incorporate additional supply chain processes or to expand the framework to other industries. The study focused on outbound logistics activities, and so excludes other supply chain functions and trading activities. The latter could be included in further studies.

\section{REFERENCES}

[1] Havenga, J.H., De Bod, A., Simpson, Z.P., Viljoen, N. \& King, D. 2016. Logistics barometer South Africa 2016. Stellenbosch University, South Africa, pp. 3 - 9.

[2] PwC. 2012. South African retail and consumer products outlook: 2012-2016. Available at: https://www.pwc.co.za/en/assets/pdf/retail-and-consumer-products-outlook-2012-2016.pdf [Accessed: 2 May 2017]

[3] Barloworld Logistics. 2016. 2016 Supplychainforesight. Frost \& Sullivan: Johannesburg, South Africa. Available at: http://barloworld-logistics.com/supply-chain-foresight/ [Accessed: 11 June 2016]

[4] Bokor, Z. \& Markovits-Somogyi, R. 2014. Applying activity-based costing at logistics service providers. Periodica Polytechnica Transportation Engineering, vol. 43, no. 2, pp. 98-105.

[5] Christopher, M. 1998. Logistics and supply chain management: Strategies for reducing cost and improving service. London: Pearson Education Limited.

[6] Cooper, R. \& Kaplan, R.S. 1988. Measure costs right, make the right decisions. Harvard Business Review, 66(5), pp. 96-103.

[7] Pirttilä T. \& Petri, H. 1995. Activity-based costing and distribution logistics management. International Journal of Production Economics, 41(1), pp. 327-33.

[8] Foster, G. \& Gupta, M. 1994. Marketing, cost management and management accounting. Journal of Management Accounting Research, 6, p. 43.

[9] CSIR. 2006. The third annual state of logistics survey for South Africa. Pretoria: Centre for Logistics, CSIR Built Environment.

[10] APICS: The Association for Operations Management. 2017. APICS Dictionary, $15^{\text {th }}$ edition. Chicago: APICS.

[11] Lin, B., Collins, J. \& Su, R.K. 2001. Supply chain costing: An activity-based perspective. International Journal of Physical Distribution \& Logistics Management, 31(10), 702-713.

[12] CSIR. 2013. 10 th annual state of logistics survey for South Africa. Pretoria: Centre for Logistics, CSIR Built Environment.

[13] Bansal, R. 2014. A comparative financial study: Evidence from selected retail companies. Journal of Finance and Investment Analysis, 3(3), pp. 13-35.

[14] Ryals L. 2008. Managing customers profitably. Chichester: John Wiley \& Sons.

[15] Hill, P. 2013. Pricing for profit: How to develop a powerful pricing strategy for your business. London: Kogan Page Ltd.

[16] Thermido, I., Arantes, A., Fernandes, C. \& Guedes, A.P. 2000. Logistics cost case study: An ABC approach. Journal of the Operational Research Society, 51(10), pp. 1148-1157.

[17] Stapleton, D., Pati, S., Beach, E. \& Julmanichoti, P. 2001. Activity-based costing for logistics and marketing. Business Process Management Journal, 10(3), pp. 584-597.

[18] Pohlen, T.L. \& La Londe, B.J. 1994. Implementing activity-based costing (ABC) in logistics. Journal of Business Logistics, 15(2), p.1.

[19] Spector, R.E. 2006. How constraints management enhances lean and six sigma. Supply Chain Management Review, January/February, 43-47.

[20] Cox, J.F. \& Spencer, M.S. 1998. The constraints management handbook. Boca Raton: CRC Press. 
[21] Sheu, C., Chen, M. \& Kovar, S. 2003. Integrating ABC and TOC for better manufacturing decision making. Integrated Manufacturing Systems, 14(5), 433-441.

[22] Simatupang, T.M., Wright, A.C. \& Ramaswami, S. 2004. Applying the theory of constraints to supply chain collaboration. Supply Chain Management: An International Journal, 9(1), 57-70.

[23] Mohr, P. \& Fourie, L. 2004. Economics: for South African students, 3rd ed. Pretoria: Van Schaik Publishers.

[24] Dugdale, D. \& Jones, T.C. 1998. Throughput accounting: Transforming practices? British Accounting Review, 30, 203-220.

[25] Ryals L. 2006. Profitable relationships with key customers: How suppliers manage pricing and customer risk. Journal of Strategic Marketing, 14(2), 101-113.

[26] Griful-Miquela, C. 2001. Activity-based costing methodology for third-party logistics companies. IAER, 7(1), 133-146.

[27] Lyly-Yrjänäinen, J. \& Paranko, J. 2001. A new approach to product costing in logistics business. $16^{\text {th }}$ International Conference on Production Research, 29.7.-3.8.2001, Prague, Czech Republic.

[28] Gulsecen, S. \& Kubat, A. 2006. Teaching ICT to teacher candidates using PBL: A qualitative and quantitative evaluation. Educational Technology \& Society, 9(2), 96. 